Prophetic: Professional, Empathy and Islamic Counseling Journal

Vol. 2, No. 2, Desember 2019, hlm. 163-176

e-ISSN : 2685-0702, p-ISSN : 2654-3958

Tersedia Online di http://syekhnurjati.ac.id/jurnal/index.php/prophetic

Email: prophetic@syekhnurjati.ac.id

\title{
Efektivitas Konseling Realita untuk Mengembangkan Kompetensi Intrapersonal Remaja
}

\author{
Herny Novianti \\ Program Studi Bimbingan Konseling Islam, Fakultas Ushuluddin Adab dan Dakwah, \\ IAIN Syekh Nurjati Cirebon \\ gusbrava_211@gmail.com
}

\begin{abstract}
Abstrak
This research aimed to produce effectiveness of reality counseling for developing adolescence intrapersonal competence. The method of research used quasiexperimental research design with one group pretest-posttest. The sample in this study were adolescence of LKSA Melati., aged 15-17 years, totaling 28 adolescents. Data was collected by intrapersonal competence instrument, arranged on the aspects of Self Knowledge, Self Direction, and Self Esteem. The results showed Reallity counseling effective to develop adolescence intrapersonal competence, increased of five indicators of Self-understanding, Self-acceptance, Self-regulation, Self-control, Self Confidence. Indicators were not significant for Self Image, and Self-utilization Recommendations showed for guidance and counseling study program, child social welfare institution (LKSA) and further research.
\end{abstract}

Key words: Reality Counseling; Intrapersonal Competence; Adolescence.

\section{PENDAHULUAN}

Remaja dalam melangsungkan kehidupannya, tidak terlepas dari permasalahanpermasalahan yang dihadapi, baik dari segi kemampuan intrapersonal maupun interpersonal. Supriatna (2010), menyatakan kemampuan intrapersonal merupakan salah satu dimensi dari kecakapan pribadi yang terfokus pada kemampuan individu untuk memahami dirinya, sedangkan kemampuan interpersonal merupakan kecakapan yang dimiliki individu dalam memahami dan bekerja sama dengan orang lain.

Terkait dengan hal tersebut, keberhasilan remaja dalam usaha untuk memperbaiki kepribadiannya bergantung pada banyak faktor, yaitu: (1) penentuan ideal-ideal yang realistik dan dapat dicapai. Jika tidak, remaja akan mengalami kegagalan, perasaan tidak mampu, dan rendah diri; (2) penilaian yang realistik mengenai kekuatan dan kelemahannya. Perbedaan yang mencolok antara kepribadian yang sebenarnya dengan ego 
ideal akan menimbulkan kecemasan, perasaan tidak nyaman, tidak bahagia, dan kecenderungan menggunakan reaksi-reaksi bertahan; (3) konsep diri (Hurlock, 1980: 235).

Pada kenyataannya, remaja sering dihadapkan pada kondisi kebingungan dalam memahami dirinya, hal tersebut dikarenakan masa remaja merupakan masa berkembangnya self-identify (kesadaran akan identitas atau jati dirinya). Syamsu Yusuf (2009: 14-15) menyatakan bahwa masa remaja dihadapkan kepada berbagai pertanyaan tentang keberadaan dirinya, akan menjadi apa dirinya. Jika remaja berhasil memahami dirinya, serta peran-perannya dalam kehidupan sosial dan memahami makna hidup beragama, maka dapat menemukan jati dirinya dan memiliki kepribadian yang sehat.

Berdasarkan perkembangan remaja, Erikson (Feist \& Feist, 2006)menyatakan bahwa remaja merupakan masa berkembangnya identity. Identity merupakan titik utama dari pengalaman remaja, karena semua krisis normatif memberikan kontribusi pada perkembangan identitas remaja. Jika remaja tidak berhasil dalam menyelesaikan pencarian identitas dirinya, maka akan kehilangan arah. Hal tersebut jelas dapat mengganggu perkembangan remaja dalam kompetensi intrapersonal.

Ketidakberhasilan remaja dalam pencapaian kompetensi intrapersonal seperti pengetahuan diri, pengarahan diri, dan pemahaman diri dialami juga oleh remaja yang tinggal di Lembaga Kesejahteraan Sosial (LKSA). Mereka sering dihadapkan dalam kebingungan memahami tentang dirinya secara memadai baik dari segi kekuatan, kelemahan, kebutuhan, maupun perasaan dan motif. Cavanagh \& Levitov (2002) menyatakan jika individu mampu berhubungan dengan dirinya secara efektif, maka berhubungan dengan orang lainpun berada kondisi efektif. Hal tersebut jelas menggambarkan bahwa kegagalan dalam berhubungan dengan diri sendiri dapat menimbulkan kegagalan dalam berhubungan dengan orang lain.

Berdasarkan hasil observasi dan wawancara awal diperoleh informasi dari pembina LKSA Melati Bandung bahwa terdapat remaja di LKSA tersebut yang mengalami hambatan terhadap pemahaman diri, pengarahan diri, serta penghargaan diri. Fenomena tersebut menguatkan bahwa remaja masih kurang dalam hubungan intrapersonal dengan dirinya sehingga mudah terbawa arus oleh lingkungannya. Pernyataan tersebut diperkuat oleh penelitian Survei (Marwati, Prihartanti, \& Hertinjung, 2016) menunjukkan 46\% remaja di LKSA mengarah pada ciri-ciri harga diri rendah. Selain itu, Novianti (2015) menyatakan 51,92\% remaja LKSA berada pada kategori harga diri yang rendah, dan 76, 92\% berada pada kategori pemahaman diri yang rendah.

Dari beberapa hasil penelitian tersebut dapat disimpulkan bahwa kompetensi intrapersonal pada remaja masih perlu untuk dikembangkan. Dalam hal ini, peran konseling realita sangat diperlukan untuk optimalisasi kompetensi intrapersonal remaja. Konseling realita dapat membantu remaja yang mengalami kesulitan dalam kom.petensi intrapersonal, sehingga remaja dapat menerima kondisi dirinya yang meliputi konsep 3R, yaitu Responsibility, Right, dan Reality. Glaser (2010) menyatakan dasar dari konseling realita adalah membantu konseli dalam memenuhi kebutuhan psikologinya, yang meliputi kebutuhan untuk mencintai dan dicintai serta kebutuhan untuk mendapatkan penghargaan. 
Berdasarkan landasan teoretis dan empiris di atas diperlukan adanya konseling untuk remaja LKSA sehingga mereka dapat meningkatkan pengetahuan diri, pemahaman diri, dan pengarahan diri. Adapun pendekatan konseling yang digunakan yaitu konseling realita, yang berasumsi bahwa: (1) manusia terlahir dengan lima kebutuhan dasar, yaitu: (a)kebutuhan bertahan (survival), (b) kebutuhan mencintai dan memiliki (love and belonging), (c) kebutuhan kekuasaan (power), (d) kebutuhan kebebasan (freedom/ independence), (e) dan kebutuhan kesenangan (fun); (2) perbedaan antara apa yang diinginkan dengan persepsi tentang apa yang diperoleh merupakan sumber utama dalam bertindak pada suatu peristiwa; (3) semua perilaku manusia dibentuk oleh tindakan (acting), pikiran (thingking), dan kondisi fisiologis (physiology); (4) perilaku manusia berasal dalam diri, karena itu manusia harus bertanggung jawab atas segala perilakunya; (5) manusia melihat dunia melalui sistem perseptual. Dengan demikian, penelitian ini difokuskan kepada Efektivitas Konseling Realitas untuk Mengembangkan Kompetensi Intrapersonal Remaja

\section{METODE PENELITIAN}

Pendekatan penelitian yang digunakan adalah pendekatan penelitian kuantitatif. Creswell (2008, hlm. 299) menyatakan bahwa penelitian kuantitatif merupakan penelitian yang bekerja dengan angka, yang datanya berwujud bilangan dan dianalisis dengan menggunakan statistik. Pendekatan kuantitatif digunakan berdasarkan alasan bahwa penelitian ini dimaksudkan untuk menjawab hipotesis penelitian yang sifatnya spesifik serta melakukan prediksi bahwa konseling realita berpengaruh terhadap perkembangan kompetensi intrapersonal.

Penelitian eksperimen yang digunakan adalah penelitian eksperimen kuasi, dimana penelitian tetap memiliki kelompok kontrol, namun tidak dapat berfungsi sepenuhnya untuk mengontrol variabel-variabel luar yang mempengaruhi pelaksanaan eksperimen (Sugiyono, 2010). Selain itu, menurut Cresswell (2008) metode eksperimen kuasi (quasi experimental) digunakan dalam penelitian eksperimen apabila mempunyai dua kelompok yang tidak dipilih secara acak. Mengingat penelitian mengenai konseling realita untuk mengembangkan kompetensi intrapersonal remaja dilakukan dalam pembelajaran sehari-hari bukan dalam kondisi laboratorium, sehingga tidak memungkinkan mengontrol variabel lain selain variabel konseling realita dan variabel kompetensi intrapersonal secara ketat. Dengan demikian, metode penelitian yang cocok dalam penelitian ini adalah metode penelitian eksperimen kuasi dengan desain nonequivalent (pretest dan posttest) control group design. Adapun desain penelitian disajikan pada Tabel 3.1 berikut.

\section{Tabel 1. Desain Penelitian}

\begin{tabular}{|l|l|l|l|}
\hline Kelas & Pretest & Perlakuan & Posttest \\
\hline Eksperimen & $\mathrm{O}_{1}$ & $\mathrm{X}$ & $\mathrm{O}_{2}$ \\
\hline Kontrol & $\mathrm{O}_{3}$ & - & $\mathrm{O}_{4}$ \\
\hline
\end{tabular}




\section{HASIL DAN PEMBAHASAN}

\section{Hasil Penelitian}

\section{Profil Kompetensi intrapersonal Remaja}

Berikut diuraikan profil remaja di LKSA Melati Kota Bandung, baik secara umum maupun secara khusus berdasarkan indikator kompetensi intrapersonal.

a. Profil Umum Kompetensi Intrapersonal Remaja

Hasil penelitian menunjukkan profil kompetensi intrapersonal di LKSA Melati Kota Bandung secara umum yaitu seperti tertera pada Tabel 2.

Tabel 2. Profil Umum Kompetensi intrapersonal Remaja LKSA Melati Tahun 2019

\begin{tabular}{|c|c|c|c|c|}
\hline No & Kategori & Kriteria Rentang Skor & Frekwensi & Persentase $(\%)$ \\
\hline 1 & Rendah & $X<130$ & 13 & $27 \%$ \\
\hline 2 & Sedang & $130 \leq X<145$ & 30 & $58.5 \%$ \\
\hline 3 & Tinggi & $X \geq 145$ & 7 & $14.5 \%$ \\
\hline \multicolumn{3}{|c|}{ Jumlah } & 52 & $100 \%$ \\
\hline
\end{tabular}

b. Profil Berdasarkan Aspek Kompetensi Intrapersonal

Kemampuan kompetensi intrapersonal pada penelitian ini terbagi ke dalam tiga aspek yaitu aspek pengetahuan diri, aspek pengarahan diri dan aspek penghargaan diri. Secara lebih rinci mengenai kompetensi intrapersonalremaja LKSA Melati Kota Bandung Tahun 2019 berdasarkan aspek dapat dijelaskan pada Tabel 3 sebagai berikut.

Tabel 3. Profil Kompetensi Intrapersonal Peserta Remaja LKSA Melati Kota Bandung Berdasarkan Aspek

\begin{tabular}{|c|c|c|c|c|}
\hline Aspek & Kategori & Frekuensi & Persentasi & \multirow{2}{*}{ Tingkat Pencapaian } \\
\hline \multirow{3}{*}{ Pengetahuan Diri } & Rendah & 14 & $26.9 \%$ & \\
\cline { 2 - 4 } & Sedang & 23 & $44.2 \%$ & \multirow{3}{*}{ Kategori Sedang } \\
\cline { 2 - 4 } & Tinggi & 15 & $28.9 \%$ & \\
\hline \multirow{3}{*}{ Pengarahan Diri } & Rendah & 16 & $30.7 \%$ & \multirow{3}{*}{ Kategori Sedang } \\
\cline { 2 - 4 } & Sedang & 21 & $76.6 \%$ & \\
\cline { 2 - 4 } & Tinggi & 15 & $7.3 \%$ & \\
\hline \multirow{3}{*}{ Penghargaan Diri } & Rendah & 18 & $34.6 \%$ & \multirow{3}{*}{ Kategori Sedang } \\
\cline { 2 - 4 } & Sedang & 21 & $40.4 \%$ & \\
\cline { 2 - 4 } & Tinggi & 13 & $25 \%$ & \\
\hline
\end{tabular}

2. Deskripsi Pelaksanaan Konseling Realita untuk Mengembangkan Kompetensi Intrapersonal Remaja

Pelaksanaan konseling realita terbagi menjadi 8 sesi layanan/pertemuan. Setiap pertemuan yang diturunkan dari tahap program, mengacu pada kesepakatan waktu yang telah ditetapkan. Adapun deskripsi dari pelaksanaan konseling realita untuk mengembangkan kompetensi intrapersonal remaja LKSA adalah sebagai berikut. 


\section{Tabel 5. Matriks Layanan Konseling Realita untuk Mengembangkan Kompetensi Intrapersonal Remaja}

\begin{tabular}{|c|c|c|}
\hline 1 & Tahapan Layanan & Tahap Awal (Orientasi) \\
\hline & Sesi Layanan & Sesi 1: Pengungkapan Kondisi Awal Remaja LKSA (Pre-Test) \\
\hline & Waktu & 1x Pertemuan (1x60 menit) \\
\hline & Tujuan & $\begin{array}{l}\text { 1. Peserta dapat memahami tujuan umum dan garis besar layanan. } \\
\text { 2. Peserta dapat memahami tujuan pengungkapan kompetensi } \\
\text { intrapersonal. }\end{array}$ \\
\hline & Deskripsi Kegiatan & $\begin{array}{l}\text { Peneliti membagikan angket kompetensi intrapersonal beserta lembar } \\
\text { jawabannya. Selanjutnya, menjelaskan cara pengisian angket dan } \\
\text { menugaskan peserta untuk mengisi lembar jawaban. Dalam hal ini, } \\
\text { peneliti menegaskan pada peserta untuk memilih jawaban yang } \\
\text { menggambarkan kondisi peserta. Berikutnya, peserta mengisi lembar } \\
\text { jawaban dengan memilih salah satu jawaban yang tersedia, kemudian } \\
\text { mengumpulkannya setelah selesai mengerjakannya. Sebelum kegiatan } \\
\text { berakhir, peneliti menyampaikan bahwa hasil pengungkapan kondisi } \\
\text { awal profil kompetensi intrapersonalakan diberikan pada pertemuan } \\
\text { berikutnya. }\end{array}$ \\
\hline & $\begin{array}{l}\text { Penunjang Teknis } \\
\text { dan Metode }\end{array}$ & $\begin{array}{l}\text { 1. Penunjang Teknis: Angket kompetensi intrapersonal. } \\
\text { 2. Metode: Penugasan. }\end{array}$ \\
\hline & Sesi Layanan & $\begin{array}{l}\text { Sesi 2: Pemahaman Umum Mengenai Kompetensi Intrapersonal } \\
\text { Berdasarkan Hasil Pre-Test }\end{array}$ \\
\hline & Waktu & 1x Pertemuan (1x60 menit) \\
\hline & Tujuan & Peserta memahami kondisi awal kompetensi intrapersonal \\
\hline & Deskripsi Kegiatan & $\begin{array}{l}\text { Peneliti membagikan lembaran hasil pengungkapan kondisi awal } \\
\text { kompetensi intrapersonal pada masing-masing peserta, kemudian } \\
\text { menjelaskannya. Berikutnya, peserta menyimak penjelasan tersebut } \\
\text { dengan melihat lembaran hasil pengungkapan kondisi awal yang telah } \\
\text { dibagikan serta diarahkan untuk berperan aktif dalam diskusi. } \\
\text { Selanjutnya, peneliti menjelaskan pentingnya layanan konseling realita } \\
\text { untuk mengembangkan kompetensi intrapersonal remaja. Setelah itu, } \\
\text { peneliti mempersilahkan peserta untuk bertanya mengenai kompetensi } \\
\text { intrapersonal. Sebelum kegiatan berakhir, peneliti menyampaikan } \\
\text { rangkaian kegiatan selanjutnya dalam rangka mengembangkan } \\
\text { kompetensi intrapersonal. }\end{array}$ \\
\hline & $\begin{array}{l}\text { Penunjang Teknis } \\
\text { dan Metode }\end{array}$ & $\begin{array}{l}\text { 1. Penunjang Teknis: Hasil pengungkapan kondisi awal kompetensi } \\
\text { intrapersonal. } \\
\text { 2. Metode: Diskusi dan tanya jawab. }\end{array}$ \\
\hline 2 & Tahapan Layanan & $\begin{array}{l}\text { Tahap Inti (Intervensi Konseling Realita yang Meliputi WDEP) } \\
\text { "W=Wants; } \quad \mathrm{D}=\text { Direction and Doing; } \quad \mathrm{E}=\text { Self-Evaluation; } \\
\mathrm{P}=\text { Planning". }\end{array}$ \\
\hline & Sesi Layanan & Sesi 1: Pemanasan dan Eksplorasi WANTS (W) \\
\hline & Waktu & 1x Pertemuan (1x60 menit) \\
\hline & Tujuan & $\begin{array}{l}\text { Peserta dapat mengembangkan kompetensi intrapersonal yang meliputi } \\
\text { indikator pemahaman diri dan penerimaan diri. }\end{array}$ \\
\hline & Deskripsi Kegiatan & $\begin{array}{l}\text { Peneliti mengemukakan tema masalah yang diangkat dari kehidupan } \\
\text { sehari-hari peserta, yaitu yang berkaitan dengan WANTS (W), yaitu } \\
\text { menjalajahi keinginan, kebutuhan dan persepsi, sehingga peserta } \\
\text { mengangap bahwa permasalahan tersebut merupakan sebuah wadah yang } \\
\text { mewajibkan mereka untuk belajar menghadapi sebuah masalah. }\end{array}$ \\
\hline
\end{tabular}




\begin{tabular}{|c|c|}
\hline & $\begin{array}{l}\text { Selanjutnya, peneliti menggambarkan permasalahan dengan jelas disertai } \\
\text { dengan contoh, yaitu melalui cerita. Permasalahan tersebut muncul dari } \\
\text { gambaran yang diberikan oleh peserta. Berikutnya, peserta menyimak } \\
\text { cerita yang dibacakan oleh peneliti. Dalam hal ini, cerita dihentikan saat } \\
\text { sebuah dilema muncul. Selanjutnya, peneliti mengajukan pernyataan } \\
\text { yang membuat peserta berpikir dan memperkirakan akhir cerita. } \\
\text { Setelah itu, peneliti dan peserta berdiskusi untuk menggambarkan } \\
\text { berbagai karakter yang akan diperankan. Penggambaran karakter terbut } \\
\text { diadasarkan atas tuntunan cerita menurut persepsi peneliti dan peserta. } \\
\text { Berikutnya, peneliti memberikan kesempatan kepada peserta untuk } \\
\text { mengemukakan karakter yang dikehendaki, sesuai dengan yang dirasakan } \\
\text { peserta. Selanjutnya, peneliti mengajukan tawaran, siapa yang akan } \\
\text { menjadi pemeran. Dalam hal ini, konselor mengarahkan konseli untuk } \\
\text { memeriksa Quality World serta bagaimana perilaku konseli ditujukan } \\
\text { untuk pindah ke persepsi tentang dunia luar yang lebih terbuka kepada } \\
\text { keinginan mereka. }\end{array}$ \\
\hline $\begin{array}{l}\text { Penunjang Teknis } \\
\text { dan Metode }\end{array}$ & $\begin{array}{l}\text { 1. Penunjang Teknis: SKLBK, papan tulis, spidol dan jurnal harian } \\
\text { kegiatan. } \\
\text { 2. Metode: Diskusi. }\end{array}$ \\
\hline Sesi Layanan & $\begin{array}{l}\text { Sesi 2: Pengaturan Adegan, Penugasan, dan Ekslorasi DIRECTION } \\
\text { (D) }\end{array}$ \\
\hline Waktu & 1x Pertemuan (1x60 menit) \\
\hline Tujuan & $\begin{array}{l}\text { Peserta dapat mengembangkan kompetensi intrapersonal yang meliputi } \\
\text { indikator pengaturan diri. }\end{array}$ \\
\hline Deskripsi Kegiatan & $\begin{array}{l}\text { Peserta yang berperan menjadi pemeran menyusun garis besar adegan } \\
\text { yang dimainkan. Dalam hal ini, peneliti menegaskan pada peserta bahwa } \\
\text { mereka tidak perlu mempersiapkan dialog khusus. Peserta diminta hanya } \\
\text { membuat sketsa adegan dan perkiraan-perkiraan tindakan seorang } \\
\text { pemain. Selanjutnya, peneliti berdiskusi dengan peserta mengenai } \\
\text { kebutuhan yang diperlukan saat adegan. Berikutnya, peneliti menugaskan } \\
\text { pada peserta yang berperan menjadi pengamat untuk menilai: (1) peran } \\
\text { yang dimainkan oleh pemain apakah sudah sesuai dengan keadaan yang } \\
\text { sebenarnya; (2) bagaimana keefektifan pelaku yang ditunjukkan } \\
\text { pemeran; (3) apakah pemeran dapat menghayati peran yang dimainkan. } \\
\text { Setelah itu, peneliti memberikan kesempatan pada peserta untuk bertanya } \\
\text { perihal pengaturan adegan dan penugasan. Dalam hal ini konselor } \\
\text { membantu konseli untuk fokus pada saat ini, sehingga konseli mampu } \\
\text { menilai kualitas perilakunya sendiri apakah perilakunya bertanggung } \\
\text { jawab, realistis, rasional atau sebaliknya. }\end{array}$ \\
\hline $\begin{array}{l}\text { Penunjang Teknis } \\
\text { dan Metode }\end{array}$ & $\begin{array}{l}\text { 1. Penunjang Teknis: SKLBK, papan tulis, spidol dan jurnal harian } \\
\text { kegiatan. } \\
\text { 2. Metode: Diskusi, dan penugasan, eksplorasi araha kehidupan saat ini. }\end{array}$ \\
\hline Sesi Layanan & Sesi 3: Pemeranan dan Eksplorasi Tindakan \\
\hline Waktu & 1x Pertemuan (1x60 menit) \\
\hline Tujuan & $\begin{array}{l}\text { Peserta dapat mengembangkan kompetensi intrapersonal yang meliputi } \\
\text { indikator pengendalian diri. }\end{array}$ \\
\hline Deskripsi Kegiatan & $\begin{array}{l}\text { Peserta memainkan peran dan menghidupkan situasi secara spontan, dan } \\
\text { saling merespon secara realistis. Dalam hal ini, pemeranan cukup } \\
\text { dilakukan secara singkat, sesuai dengan tingkat kesulitan dan } \\
\text { kompleksitas masalah serta jumlah pemeran yang dilibatkan. Selanjutnya } \\
\text { peneliti dan peserta melakukan diskusi dan evaluasi mengenai penafsiran }\end{array}$ \\
\hline
\end{tabular}




\begin{tabular}{|c|c|c|}
\hline & & $\begin{array}{l}\text { terhadap pemeranan. Berikutnya, peneliti memberikan kesempatan } \\
\text { kepada peserta untuk bertanya mengenai pemeranan. Dalam hal ini, } \\
\text { konselor mengarahkan konseli agar memiliki pengendalian diri yang } \\
\text { memadai. }\end{array}$ \\
\hline & $\begin{array}{l}\text { Penunjang Teknis } \\
\text { dan Metode }\end{array}$ & $\begin{array}{l}\text { 1. Penunjang Teknis: SKLBK, papan tulis, dan spidol. } \\
\text { 2. Metode: Bermain peran dan tanya jawab. }\end{array}$ \\
\hline & Sesi Layanan & Sesi 4: Eksplorasi Self-Evaluation \\
\hline & Waktu & 1x Pertemuan $(1 \times 60$ menit $)$ \\
\hline & Tujuan & $\begin{array}{l}\text { Peserta dapat mengembangkan kompetensi intrapersonal yang meliputi } \\
\text { indikator pencintraan diri dan percaya diri. }\end{array}$ \\
\hline & Deskripsi Kegiatan & $\begin{array}{l}\text { Peneliti meminta peserta membuat evaluasi, seperti:" Apakah perilaku } \\
\text { saat ini memiliki kesempatan yang baik untuk mendapatkan keinginan } \\
\text { sat ini dalam hal pencapaian tujuan?" Proses Self-Evaluation sangat } \\
\text { penting untuk mengevaluasi diri melalui peningkatan pencintraan diri } \\
\text { dan percaya diri positif. }\end{array}$ \\
\hline & $\begin{array}{l}\text { Penunjang Teknis } \\
\text { dan Metode }\end{array}$ & $\begin{array}{l}\text { 1. Penunjang Teknis: SKLBK, papan tulis, dan spidol. } \\
\text { 2. Metode: Bermain peran dan tanya jawab. }\end{array}$ \\
\hline & Sesi Layanan & Sesi 5: Berbagi Pengalaman dan Pengambilan Kesimpulan \\
\hline & Waktu & 1x Pertemuan $(1 \times 60$ menit $)$ \\
\hline & Tujuan & $\begin{array}{l}\text { Peserta dapat mengembangkan kompetensi intrapersonal yang meliputi } \\
\text { indikator pemanfaatan diri. }\end{array}$ \\
\hline & Deskripsi Kegiatan & $\begin{array}{l}\text { Peneliti mengajak peserta untuk berdiskusi mengenai berbagai } \\
\text { pengalaman tentang permainan peran yang dilakukan. Hal tersebut } \\
\text { dilakukan agar peserta dapat bercermin pada orang lain untuk lebih } \\
\text { memahami dirinya. Selanjutnya peneliti memberikan kesempatan pada } \\
\text { peserta untuk bertanya. Dalam hal ini, konseli diarahkan pada situasi } \\
\text { memahami perilakunya yang tidak bertanggung jawab, dan kemudian } \\
\text { konseli menyusun rencana-rencana yang realistis sehingga tingkah } \\
\text { lakunya menjadi lebih baik yang memiliki identitas yang optimal. } \\
\text { Berikutnya peneliti bersama peserta mengambil kesimpulan dari kegiatan } \\
\text { konseling realita. }\end{array}$ \\
\hline & $\begin{array}{l}\text { Penunjang Teknis } \\
\text { dan Metode }\end{array}$ & $\begin{array}{l}\text { 1. Penunjang Teknis: SKLBK, papan tulis, spidol dan jurnal harian } \\
\text { kegiatan. } \\
\text { 2. Metode: Diskusi. }\end{array}$ \\
\hline 3 & Tahapan Layanan & Tahapan Akhir (Refleksi) \\
\hline & Sesi Layanan & Refleksi (Post-Test) \\
\hline & Waktu & 1x Pertemuan (1x60 menit) \\
\hline & Tujuan & \\
\hline & Deskripsi Kegiatan & $\begin{array}{l}\text { Peneliti membagikan angket kompetensi intrapersonal beserta lembar } \\
\text { jawabannya. Selanjutnya, menjelaskan cara pengisian angket dan } \\
\text { menugaskan peserta untuk mengisi lembar jawaban. Dalam hal ini, } \\
\text { peneliti menegaskan pada peserta untuk memilih jawaban yang } \\
\text { menggambarkan kondisi peserta. } \\
\text { Berikutnya, peserta mengisi lembar jawaban dengan memilih salah satu } \\
\text { jawaban yang tersedia, kemudian mengumpulkannya setelah selesai } \\
\text { mengerjakannya. }\end{array}$ \\
\hline & $\begin{array}{l}\text { Penunjang Teknis } \\
\text { dan Metode }\end{array}$ & $\begin{array}{l}\text { 1. Penunjang Teknis: Kompetensi interpersonal. } \\
\text { 2. Metode: Penugasan. }\end{array}$ \\
\hline
\end{tabular}




\section{Efektivitas Konseling Realita untuk Mengembangkan Kompetensi Intrapersonal Remaja}

Pengujian efektivitas konseling realita untuk mengembangkan kompetensi intrapersonal remaja LKSA Melati Tahun 2019 dilakukan dengan analisis statistik non parametik yaitu: (a) uji Man Whitney terhadap gain score untuk membandingkan kelompok eksperimen dan kontrol, dan (b) uji Wilcoxon Signed Rank pada kelompok eksperimen untuk membandingkan skor sebelum dan sesudah diberikan konseling intrapersonal.

Hipotesis penelitian ini yaitu: "Konseling realita efektif untuk mengembangkan kompetensi intrapersonal remaja"

Adapun hipotesis statistiknya adalah sebagai berikut:

$\mathrm{H}_{\mathrm{o}}: \mu_{\text {eksperimen }}=\mu$ kontrol

$\mathrm{H}_{1}: \mu$ eksperimen $>\mu$ kontrol

a. Uji Mann Whitney terhadap Gain Score

Data pengisian angket kompetensi intrapersonal yang telah diperoleh dari kelompok eksperimen dan kontrol dianalisis menggunakan analisis statistik nonparametrik uji Mann Whitney terhadap gain score antara kelompok eksperimen dan kelompok kontrol.

Tabel 5. Uji Whitney U Terhadap Gain Score Kelas Eksperimen dan Kontrol Hypothesis Test Summary

\begin{tabular}{|c|c|c|c|c|}
\hline & Null Hypothesis & Test & Sig. & Decision \\
\hline 1 & $\begin{array}{l}\text { The distribution of VAROOOOD } \\
\text { Same across o ategories of } \\
\text { VAROOOOZ. }\end{array}$ & $\begin{array}{l}\text { Independent- } \\
\text { is th } 6 \text { amples } \\
\text { hann- } \\
\text { Whitney } U \\
\text { Test }\end{array}$ & $.000^{1}$ & $\begin{array}{l}\text { Reject the } \\
\text { nuil } \\
\text { hypothesis. }\end{array}$ \\
\hline
\end{tabular}

Asymptotic significances are displayed. The significance level is 05 .

1 Exact significance is displayed for this test.

Berdasarkan hasil analisis data Uji Mann Whitney $U$ terhadap gain score, dengan bantuan SPSS 17, nilai sig adalah 0,01, maka Ho ditolak. Hal ini menunjukkan bahwa hipotesis nol $\left(\mathrm{H}_{0}\right)$ ditolak, yang berarti terdapat perbedaan yang signifikan kompetensi intrapersonal remaja yang diberi perlakuan dengan yang tidak diberikan perlakuan konseling realita pada remaja LKSA Melati Tahun 2019. Dengan demikian, dapat disimpulkan bahwa konseling realita efektif untuk mengembangkan kompetensi intrapersonal remaja.

b. Uji Wilcoxon Signed Rank

Untuk mengetahui efektifitas konseling realita untuk mengembangkan kompetensi intrapersonal remaja pada kelompok eksperimen dilakukan uji Wilcoxon satu sisi. Statistik uji yang digunakan untuk pengujian hipotesis $\mathrm{H}_{0}: \mu_{\text {posttest }-\mu \text { pretest }}=0$, $\mathrm{H}_{1}: \mu_{\text {posttest }-\mu \text { retest }}>0$ adalah statistik uji $w_{+}$yang menyatakan banyaknya rang yang berasal dari selisih positif. Pada uji statistik satu sisi kanan, hipotesis nol ditolak jika jika $w_{+}>w_{\text {tabel }}$. Hasil perhitungan uji Wilcoxon menunjukkan $w_{+}$sebesar 120 dan $w_{\text {tabel }}$ 
sebesar 30. Taraf keyakinan $(\alpha)$ yang digunakan sebagai kriteria dasar pengambilan keputusan hipotesisnya adalah pada taraf signifikansi 5\% atau $\alpha=0,05$. Dengan menggunakan kriteria tolak hipotesis nol jika $w_{+}>w_{\text {tabel }} 120>30$, maka hipotesis nol $\mathrm{H}_{0}$ ditolak. Hal tersebut menunjukkan konseling realita untuk mengembangkan kompetensi intrapersonal remaja LKSA Melati Tahun 2019.

Adapun uji efektivitas konseling realita berdasarkan setiap indikator kompetensi intrapersonal menunjukkan bahwa pada pemahaman diri mempunyai $w_{+}>$ $w_{\text {tabel }}$ yakni 38>30 yang berarti indikator tersebut efektif meningkat setelah diberikan perlakuan. Indikator penerimaan diri mempunyai $w_{+}>w_{\text {tabel }}$ yakni $45>30$ yang berarti indikator tersebut tersebut efektif meningkat setelah diberikan perlakuan. Indikator terhadap pengaturan diri mempunyai $w_{+}>w_{\text {tabel }}$ yakni 43>30 yang berarti indikator tersebut efektif meningkat setelah diberikan perlakuan. Indikator pengendalian diri terhadap perubahan mempunyai $w_{+}>w_{\text {tabel }}$ yakni 55>30 yang berarti indikator tersebut efektif meningkat setelah diberikan perlakuan. Indikator percaya diri mempunyai $w_{+}>$ $w_{\text {tabel }}$ yakni 38,5>30 yang berarti indikator tersebut efektif meningkat setelah diberikan perlakuan.

Indikator pencitraan diri mempunyai $w_{+}<w_{\text {tabel }}$ yakni $21,5<30$ yang berarti perlakuan tidak efektif pada indikator tersebut. Indikator Indikator pemanfaatan diri $w_{+}$ $<w_{\text {tabel }}$ yakni $21<30$ yang berarti perlakuan tidak efektif pada indikator tersebut. Keefektifan konseling realita ditinjau pada setiap indikator dapat dilihat pada Tabel 6 berikut.

Tabel 6. Uji Efektivitas Konseling Realita Berdasarkan Indikator Komptensi Intrapersonal

\begin{tabular}{|c|c|c|c|c|}
\hline Indikator & Kelompok & w+ & $\mathbf{W}_{\text {tabel }}$ & Keterangan \\
\hline \multirow[t]{2}{*}{ Pemahaman Diri } & Pretest & \multirow{2}{*}{38} & \multirow{2}{*}{30} & \multirow{2}{*}{ Signifikan } \\
\hline & Postest & & & \\
\hline \multirow[t]{2}{*}{ Penerimaan Diri } & Pretest & \multirow{2}{*}{45} & \multirow{2}{*}{30} & \multirow{2}{*}{ Signifikan } \\
\hline & Postest & & & \\
\hline \multirow[t]{2}{*}{ Pengaturan Diri } & Pretest & \multirow{2}{*}{43} & \multirow{2}{*}{30} & \multirow{2}{*}{ Signifkan } \\
\hline & Postest & & & \\
\hline \multirow[t]{2}{*}{ Pengendalian Diri } & Pretest & \multirow{2}{*}{55} & \multirow{2}{*}{30} & \multirow{2}{*}{ Signifikan } \\
\hline & Postest & & & \\
\hline \multirow[t]{2}{*}{ Percaya Diri } & Pretest & \multirow{2}{*}{38,5} & \multirow{2}{*}{30} & \multirow{2}{*}{ Signifikan } \\
\hline & Postest & & & \\
\hline \multirow[t]{2}{*}{ Pencintraan Diri } & Pretest & \multirow{2}{*}{21,5} & \multirow{2}{*}{30} & \multirow{2}{*}{ Tidak Signifikan } \\
\hline & Postest & & & \\
\hline \multirow[t]{2}{*}{ Pemanfaatan Diri } & Pretest & \multirow{2}{*}{21} & \multirow{2}{*}{30} & \multirow{2}{*}{ Tidak Signifikan } \\
\hline & Postest & & & \\
\hline
\end{tabular}




\section{Pembahasan}

\section{Profil Umum Kompetensi Intrapersonal Remaja LKSA}

Hasil penelitian menunjukkan bahwa profil umum kompetensi intrapersonal remaja LKSA di Kota Bandung Tahun 2019 berada pada kategori sedang. Dalam hal ini, remaja sudah memahami dirinya namun belum mampu secara optimal untuk mengetahui kelemahan dan kelebihan dalam diri. kurang mampu mengendalikan dirinya; kurang dapat mengatur diirnya sendiri, kurang tertib dan disiplin dalam menjalankan jadwal kegiatan sehari-harinya, kurang memiliki citra diri yang baik dan kurang rasa kepercayaan dirinya, selain itu dirinya masih merasa kurang bermanfaat untuk orang lain.

Terkait dengan hal tersebut, Cavanagh (2002:203) mengungkapkan aspek aspek yang mempengaruhi kompetensi intrapersonal, "intrapersonal relationship are actuality based on three competencies: self-knowledge, self-direction, and self-esteem. Secara profil umum, Remaja LKS berada pada kategori sedang, dalam hal ini remaja tersebut sudah memiliki memiliki pengetahuan diri namun belum optimal, sehingga remaja cenderung belum memiliki persepsi yang akurat akan dirinya maupun kepada orang lain. Selain itu juga remaja tersebut belum terampil dalam memahami dirinya. Selaras dengan itu Santrock (2002) menyatakan remaja yang kurang mempunyai pengetahuan dirinya, akan mengalami masalah seperti: (1) tampilan perilaku yang kurang memadai sebagai akibat pengaruh bagian diri yang tidak diketahui, (2) mengasingkan diri, (3) ketidakmampuan dalam membuat keputusan, (4) memproyeksikan bagian diri yang tidak diketahui pada orang lain.

Tingkat pengetahuan diri dalam kategori sedang tersebut, perlu ditingkatkan, sehingga remaja mampu melihat pribadinya secara utuh, yang meliputi fisik, emosi, intelektual, spiritual dan sosial. Termasuk pesepsi terhadap potensi yang dimilikinya. Santrock (2002) menyatakan bahwa pengethuan diri setiap remaja dapat diperbaiki dengan meningkatkan identitas pribadi maupun identitas social, sehingga, remaja memiliki cara pandang yang dinamis dalam menyelesaikan masalahnya.

Selanjutnya, pada aspek pengarahan diri, berada pada kategori sedang, dalam hal ini remaja sudah memiliki daya atau kekuatan diri, namun belum mampu bertanggung jawab terhadap konsekuensi dari perilakunya. Cavanagh (2002) menyatakan individu yang memiliki pengarahan diri yang tidak baik, cenderung akan menghadapi: (1) kesulitan dalam mengambil keputusan, (2) kurang mampu menghadapi kegagalan, (3) keenganan dalam menghadapi resiko, (4) generalisasi dari satu aspek ke aspek lainnya, (5) beridentifikasi terhadap kepercayaan diri orang lain.

Dengan demikian, tingkat pengarahan diri dalam kategori sedang tersebut, perlu ditingkatkan, sehingga remaja mampu mempercayai akan kecakapan, persepsi, maupun motif tentang dirinya sendiri. Adanya pengarahan diri yang positif (Suherman et al., 2014) dapat mendorong remaja untuk memiliki kepekaan, inisiatif, dan responsitivitas dalam melihat peluang peluang yang tersedia, serta memiliki 
kemandirian dan tanggung jawab dalam menetapkan serangkaian pilihan tindakan guna memfasilitasi pencapaian tujuan yang ingin diraihnya.

Aspek ketiga kompetensi intrapersonal yaitu harga diri (Self Esteem), remaja LKSA memiliki penghargaan diri dalam kategori sedang, hal ini berarti bahwa remaja LKSA sudah memiliki cara pandang tentang peran dirinya yang bermanfaat namun belum memiliki penghargaan diri yang optimal. Rosenberg (1965) menyatakan harga diri merupakan sikap positif atau negatif seseorang akan dirinya secara keseluruhan. Harga diri juga dapat berhubungan dengan dimensi spesifik, seperti kemampuan akademik, kecakapan sosial, penampilan fisik, atau harga diri kolektif.

Selaras dengan itu, Yusuf dan Nurihsan (2008: 200) mengungkapkan faktorfaktor yang menyebabkan remaja mengalami kegagalan dalam melaksanakan tugas perkembangan karena kurangnya penghargaan diri positif dalm dirinya, pengarahan diri, dan pengetahuan diri. Untuk mengatasi hal tersebut diperlukan layanan konseling realita. Dalam hal ini, konseling ditujukan agar remaja mampu berperilaku realistis dan bertanggung jawab sehingga dapat mencapai otonomi.

\section{Efektivitas Konseling Realita untuk Mengembangkan Kompetensi Intrapersonal Remaja}

Efektivitas konseling realita ditinjau dari segi aspek beserta indikator yang efektif dan tidak efektif serta analisis terhadap faktor yang tidak efektif dalam proses pelaksanaan di lapangan. Ketiga aspek yang diberikan kepada remaja pada proses pelaksanaan konseling realita yaitu: (1) aspek pengetahuan diri yang meliputi indikator pemahaman diri dan penerimaan diri (2) aspek pengarahan yang meliputi pengaturan diri dan pengalihan diri; (3) aspek penghargaan diri yang meliputi pencintraan diri, pemanfaatan diri dan percaya diri.

Pengujian efektivitas konseling realita dilakukan juga berdasarkan indikator, dan ditemukan dua indikator yang tidak efektif, yaitu pencintraan diri dan pemanfaatan diri. Terkait dengan citra diri (Mappiare, 2010: 73), berasal dari istilah self-concept atau sering disebut self-image. Istilah tersebut merujuk pada pandangan atau pengertian seseorang terhadap dirinya sendiri. citra diri berkenaan dengan pandangan seseorang terhadap dirinya baik tentang fisik maupun psikisnya. Dalam hal ini, ada kekhasan dari orang ke orang dalam citra dirinya secara fisik dan citra dirinya secara psikologis, dan hal demikiian ini tidak lepas dari pandangan lingkungan terhadap diri seseorang. Remaja yang mengalami pencintraan diri negatif cenderung mengalami keraguan dalam pengambilan keputusan dan aspirasi aspirasi bagi masa depannya.

Fakta yang ditemukan selama pelaksanaan konseling realita pada indikator citra diri memang lebih rendah. Hal tersebut terindikasi dari sebagian remaja LKSA Melati yang cenderung memiliki pandangan negatif terhadap fisik maupun psikisinya. Upaya yang dapat dilakukan untuk menumbuhkan pencintraan diri positif remaja LKSA yaitu dengan mengembangkan empat pola "E" (Rosenbaum, 2012, 71-72). Adapun pelaksanaannya yaitu dengan pengembangan: (1) Experience atau 
pengalaman-pengalaman sehari -hari yang dilakukan atau telah dilakukan; 2) Exposure atau keterbukaan bagian lain dari pembentukan diri adalah keterbukaan untuk orang lain serta keterbukaan untuk ide-ide baru; 3) Education atau pendidikan merupakan bagian dari pengalaman dan keterbukaan; dan 4) Environment atau lingkungan merupakan gaya hidup yang diadopsi sebagai milik sendiri.

Berikutnya, indikator yang tidak signifikan adalah pemanfaatan diri. Fakta yang ditemukan selama pelaksanaan konseling realita, yaitu terdapat remaja yang masih memiliki pandangan bahwa dirinya tidak bermanfaat. Terkait dengan hal tersebut, perlu adanya perbaikan cara pandang remaja terhadap dirinya, seperti yang dinyatakan Hurlock (1980: 235), keberhasilan remaja dalam usaha untuk memperbaiki kepribadiannya bergantung pada banyak faktor, yaitu: (1) penentuan ideal-ideal yang realistik dan dapat dicapai. Jika tidak, remaja akan mengalami kegagalan, perasaan tidak mampu, dan rendah diri; (2) penilaian yang realistik mengenai kekuatan dan kelemahannya. Perbedaan yang mencolok antara kepribadian yang sebenarnya dengan ego ideal akan menimbulkan kecemasan, perasaan tidak nyaman, tidak bahagia, dan kecenderungan menggunakan reaksi-reaksi bertahan; (3) konsep diri.

Berkaitan dengan pendapat Hurlock, Glasser (Barriyah, Hastini, dan Sari, 2018) menyatakan pecapaian kesuksesan identitas terikat pada konsep 3R, yaitu keadaan dimana individu mampu menerima kondisi yang dialami serta menunjukkan total behavior (perilaku total), yaitu dengan melakukan (doing), berfikir (thingking), merasakan (feeling) dan menunjukkan respon fisiologis (psyology) dengan bertanggungjawab (responsibility) sesuai realita. Melalui konseling realita, remaja LKSA diarahkan untuk fokus pada saat ini. Glasser menyatakan bahwa tujuan dari konseling realita yaitu membantu konseli menilai kualitas perilakunya sendiri apakah perilakunya sudah realistis, rasional, dan tanggung jawab atau sebaliknya.

\section{Keterbatasan Penelitian}

Keterbatasan penelitian antara lain: a) rumusan konseling realista, b) jumlah subjek penelitian, dan c) proses pelaksanaan konseling realistis.

a. Rumusan konseling realita

Konseling realita seharusnya bukan hanya menyentuh aspek kompetensi intrapersonal saja namun juga menyentuh aspek kompetensi interpersonal yang meliputi indikator peka terhadap diri dan orang lain, nyaman dengan diri sendiri dan orang lain, ekspektasi yang realities tentang diri dan orang lain, dan perlindungan diri dalam situasi interpersonal. Selain itu juga untuk mengembangkan kompetensi intrapersonal remaja, perlu dilaksanakan konseling realita dengan sesi konseling selama $12 \mathrm{x}$ pertemuan sehingga hasilnya lebih komprehensif. Terkait dengan rumusan konseling realita yang dibuat oleh peneliti masih memiliki keterbatasan, bisa jadi baru menyentuh aspek luar dari kompetensi intrapersonal. 
b. Subjek penelitian

Banyaknya jumlah subjek penelitian saat melaksanakan eksperimen kuasi sedikit, idealnya subjek penelitian tidak hanya remaja LKSA Melati saja, namun juga melibatkan remaja dari LKSA lain. Meskipun demikian, dalam studi ini dapat dilihat peningkatan perkembangan kompetensi intrapersonal remaja setelah diberikan perlakuan konseling realita, sehingga secara subjektif dapat disimpulkan bahwa studi ini sudah cukup representatif.

c. Proses pelaksanaan konseling realita

Pada saat implementasi konseling realita tempat yang digunakan masih terbatas dalam ruangan in-door, sangat memungkinkan akan berdampak efektif jika memanfaatkan alam terbuka, karena konseli akan merasa lebih nyaman dan menemukan suasana yang berbeda. Selain itu juga, layanan konseling realita ini tidak disertai dengan tindak lanjut untuk melakukan pemantauan perkembangan kompetensi intrapersonal remaja LKSA Melati, sehingga dinamika perubahan kompetensi intrapersonal tidak dapat terpantau dengan baik.

\section{SIMPULAN}

Penelitian ini menghasilkan konseling realita untuk mengembangkan kompetensi intrapersonal remaja, yang telah dikembangkan secara teoretik dan empiris. Untuk menghasilkan model konseling tersebut ditempuh prosedur penelitian yang meliputi studi pendahuluan, pengembangan konseling realita, uji kelayakan konseling realita, dan uji coba konseling realita. Hasil studi menunjukkan bahwa konseling realita efektif untuk mengembangkan kompetensi intrapersonal remaja. Profil umum kompetensi intrapersonal remaja LKSA menunjukkan kategori tidak efektif pada indikator pencinntraan diri dan pemanfaatan diri. Hal tersebut dikarenakan remaja LKSA cenderung mempunyai kepribadian inferior, pasif, apatis, dan menarik diri. Dengan kata lain, konseling realita terbukti efektif untuk mengembangkan hampir semua indikator kompetensi intrapersonal kecuali pada indikator pencintraan diri dan pemanfaatan diri tidak signifikan.

\section{DAFTAR PUSTAKA}

Bariyyah, Hastini, \& Wulan. (2018). Konseling Realita untuk Meningkatkan Tanggung Jawab Belajar Siswa. Ejournal.unp.ac.id. 7(1). 1-8.

Cavanagh \& Levitov. (2002). The Counseling Experience A Theoritical and Practical Approach. Illinois: Waveland Press.

Creswell John W. (2008), Educational Research, New Jersey: Pearson Education.

Feist, J. \& Feist, G. (2006). Theories of Personality. Yogyakarta: Pustaka Pelajar.

Glasser, W. (2010). Reality therapy in action. New York, NY, US: HarperCollins Publishers. 
Heppner, P., Wampold, E.B., \& Kivlinghan, M.D. (2008). Research Design in Counseling. USA: Thomson Higher Education.

Hurlock, E. (1980). Adolescent development. Tokyo: Mc Graw- Hill Kogakusha.

Marwati1, Prihartanti, \& Hertinjung. (2016).1(1). Pelatihan Berpikir Optimis untuk Meningkatkan Harga Diri pada Remaja di Pani Asuhan. Journal Indigenous. 1(1).23-31.

Santrock, JW. (2002). Life Span Development. Alih bahasa : Achmad Chusairi dan Juda Damanik. Editor : Wisnu Chandra Krstiaji dan Yati Sumiharti. Jakarta : Erlangga.

Sugiono. (2010). Metode Penelitian Pendidikan Pendekatan Kuantitatif, Kualitatif, dan $R \& D$.Bandung: Alfabeta.

Suherman, Ilfiandra, \& NA, S. (2014). Model Bimbingan Untuk Meningkatkan Kecakapan Pengarahan Diri.

Supriatna, Mamat (2010). Model Konseling Aktualisasi Diri Untuk Mengembangkan Kecakapan Pribadi Mahapeserta didik. Disertasi (tidak diterbitkan). Bandung: Sekolah Pascasarjana UPI.

Mappiare, Andi. (2010). Pengantar Konseling dan Psikoterapi. Jakarta: Rajawali Press.

Novianti, Herny. (2016). Bimbingan Sosial untuk Meningkatkan Perilaku Asertif Remaja LKSA. Tesis. Bandung: Sekolah Pascasarjana UPI.

Yusuf, S. ( 2009). Program Bimbingan dan Konseling di Sekolah. Bandung: Rizqi.

Yusuf, S. \& Nurihsan, J. (2011). Landasan Bimbingan dan Konseling. Bandung: Rosda. 